\title{
Penyediaan Air Bersih Mandiri Permukiman Pesisir Kota Balikpapan berdasarkan Tingkatan Partisipasi
}

\author{
Mega Ulimaz ${ }^{1 *}$, Risa Andini \\ ${ }^{1,2}$ Institut Teknologi Kalimantan \\ *megaulimaz@itk.ac.id
}

\begin{abstract}
Kelurahan Baru Tengah is a sub-district in Kecamatan Balikpapan Barat which is the coastal area. This sub-district is dominated by settlement activities. Based on the Spatial Plan of Balikpapan City Year 2012-2032, the target of providing the needs of clean water of Balikpapan Barat reach $100 \%$ in 2030. However, Kelurahan Baru Tengah is an area that until now the providing of clean water needs has not been evenly distributed. In addition, there has been no guidance of community participation in the provision of clean water in this area. This study aims to formulate the guidance of the water supply community-based participation by using Analytical Hierarchy Process. The result of the analysis that has been done is the communities in Kelurahan Baru Tengah can participate at the level of Delegated Power in the form of their idea. The results obtained from this research are expected to be a reference for the provision of clean water in Kelurahan Baru Tengah which involves local community participation.

Keywords : clean water provision, community participation, coastal area, analytical hierarchy process.
\end{abstract}

\begin{abstract}
Abstrak
Kelurahan Baru Tengah adalah salah satu kelurahan di Kecamatan Balikpapan Barat yang merupakan kawasan pesisir. Kelurahan ini didominasi oleh kegiatan permukiman. Berdasarkan Rencana Tata Ruang Wilayah Kota Balikpapan Tahun 2012-2032, target pemenuhan kebutuhan air bersih di Kecamatan Balikpapan Barat mencapai $100 \%$ pada tahun 2030. Namun, Kelurahan Baru Tengah merupakan kawasan yang sampai saat ini pemenuhan kebutuhan air bersihnya belum merata. Selain itu, belum ada arahan bentuk partisipasi masyarakat dalam penyediaan air bersih di kawasan ini. Penelitian ini bertujuan untuk merumuskan arahan penyediaan air bersih berbasis partisipasi masyarakat dengan menggunakan Analytical Hierarchy Process. Hasil dari analisis yang telah dilakukan adalah masyarakat Kelurahan Baru Tengah dapat berpartisipasi pada tingkatan Delegated Power dalam bentuk pikiran. Hasil yang diperoleh dari penelitian ini diharapkan dapat menjadi acuan penyediaan air bersih di Kelurahan Baru Tengah yang melibatkan partisipasi masyarakat setempat.

Kata kunci : penyediaan air bersih, partisipasi masyarakat, kawasan pesisir, analytical hierarchy process
\end{abstract}

\section{Pendahuluan}

Infrastruktur merupakan suatu aspek yang mempercepat pembangunan wilayah. Ketersediaan infrastruktur dapat meningkatkan akses masyarakat terhadap sumberdaya sehingga dapat meningkatkan produktifitas dan efisiensi dan pada akhirnya dapat meningkatkan pertumbuhan ekonomi [1]. Keberadaan infrastruktur merupakan satu kesatuan yang tidak dapat dipisahkan dan sudah menjadi kebutuhan dasar masyarakat dan pemerintah. Peran infrastruktur terhadap perkembangan wilayah dan kota memiliki kontribusi yang sangat signifikan, baik pada aspek ekonomi, sosial-masyarakat, maupun kelestarian lingkungan.

Penyediaan infrastruktur yang berpengaruh terhadap perkembangan wilayah salah satunya ialah penyediaan air bersih. Penyediaan air bersih dilakukan untuk memenuhi kebutuhan air bersih tidak hanya manusia, namun juga lingkungan yang menjadi tempat tinggal masyarakat dan memengaruhi 
kualitas sumber daya manusia di suatu wilayah [2]. Air bersih tidak terpisahkan dari kehidupan manusia. Air bersih menjadi pendukung dalam setiap bentuk kegiatan manusia. Berbagai bentuk kegiatan yang dilakukan oleh manusia membutuhkan air bersih sebagai salah satu penunjang utama, seperti makan, minum, mandi, mencuci, dan kegiatan lainnya yang juga menjadi penyokong kehidupan.

Berdasarkan Rencana Tata Ruang Wilayah Kota Balikpapan tahun 20122032, pengembangan prasarana air bersih di Kecamatan Balikpapan Barat diarahkan untuk meningkatkan ketersediaan air bersih melalui konsep perlindungan potensi badan air, meningkatkan pelayanan air bersih bagi masyarakat, air baku untuk pertanian, dan kelestarian Daerah Aliran Sungai. Sasaran pengembangan prasarana sumberdaya air salah satunya ialah tercapainya pelayanan air bersih mencapai $100 \%$ penduduk di tahun 2030. Kelurahan Baru Tengah merupakan kelurahan yang menjadi bagian dari kawasan pesisir Kota Balikpapan. Kelurahan ini terletak di Kecamatan Balikpapan Barat, dan menjadi bagian dari area Teluk Balikpapan. Kelurahan Baru Tengah mempunyai luas wilayah sebesar 57 hektar [3]. Jenis penggunaan lahan terbanyak di Kelurahan Baru Tengah adalah permukiman, yakni sebesar 43 hektar dengan persentase $75 \%$ dari luas wilayah kelurahan [4]. Berdasarkan hal tersebut, dua kelurahan tersebut tidak luput dari tingginya kebutuhan air bersih sebagai penunjang kehidupan masyarakat.

Kelurahan Baru Tengah merupakan suatu wilayah di Kecamatan Balikpapan Barat yang mempunyai potensi air tanah yang kecil. Kelurahan tersebut memiliki sebaran air tanah yang kurang produktif dibandingkan dengan wilayah lain di Kota Balikpapan [4]. Berdasarkan data dari BPS Kota Balikpapan tahun 2016, penggunaan sumur pompa baik dalam maupun dangkal berkisar 6\% dari jumlah keseluruhan pengguna air bersih. Pada area yang memiliki elevasi rendah terhadap permukaan laut, masyarakat dapat memanfaatkan air yang terdapat di bawah permukaan tanah. Namun, pada area yang memiliki elevasi tinggi terhadap permukaan laut, masyarakat tidak dapat memanfaatkan air yang terdapat di bawah permukaan tanah disebabkan karena ketersediaannya yang minim di area tersebut.

Sementara itu, berdasarkan wawancara dengan tokoh masyarakat setempat, untuk memenuhi kebutuhan air bersih, masyarakat Kelurahan Baru Tengah melakukan beberapa upaya. Upaya-upaya tersebut di antaranya dengan membuat sumur permukaan, membeli air bersih, serta menampung air hujan. Pembuatan sumur dilakukan sebagian kecil masyarakat untuk memenuhi kebutuhan air bersih dan dibangun secara pribadi di rumah masingmasing masyarakat. Selain itu, masyarakat membeli air bersih per tangki atau tandon dari PDAM Kota Balikpapan atau beberapa pihak swasta yang menjual air bersih. Penampungan air hujan dilakukan oleh masyarakat saat hujan tiba. Tiga upaya tersebut dilakukan oleh masyarakat Kelurahan Baru Tengah untuk memenuhi kebutuhan air bersih mereka masingmasing, dan masih dilakukan serta digunakan secara pribadi individu.

Saat ini, Kota Balikpapan belum memiliki suatu arahan yang mengatur tentang adanya partisipasi masyarakat dalam penyediaan air bersih. Kelurahan Baru Tengah juga saat ini belum memiliki arahan yang diberlakukan untuk partisipasi masyarakat dalam penyediaan air bersih. Penyediaan air bersih di wilayah penelitian masih diupayakan secara individual dan tidak diberikan pedoman yang dapat memudahkan masyarakat untuk memenuhi kebutuhan air bersih. Mengingat bahwa 
masyarakat Kelurahan Baru Tengah memiliki upaya pemenuhan kebutuhan air bersih yang potensial, maka partisipasi masyarakat dapat menjadi basis pengembangan penyediaan air bersih. Berdasarkan kondisi tersebut, perlu adanya kajian untuk mengembangkan upaya penyediaan air bersih di Kelurahan Baru Tengah guna memenuhi penyediaan air bersih.

\section{Metoda Penelitian}

Analytical Hierarchy Process atau Analisis AHP ditampilkan dalam bentuk hirarki yang terdiri atas tujuan, kriteria, dan sub kriteria serta aternatif untuk setiap permasalahan atau keputusan. Pada analisis AHP, terdapat struktur hirarki yang memungkinkan pengambilan keputusan memasukkan semua faktor penting dan mengatur posisinya sesuai sesuai kepentingan.

Analisis AHP adalah prosedur yang berbasis matematis dan sesuai untuk kondisi evaluasi atribut-atribut kualitatif. Atribut-atribut tersebut secara matematik dikuantitatif dalam perbandingan berpasangan. Analytical Hierarchy Process atau biasa disebut dengan AHP digunakan untuk menganalisis variabel dampak [5]. AHP merupakan suatu model pendukung keputusan yang dikembangkan oleh Thomas L. Saaty. Model pendukung keputusan ini akan menguraikan masalah multi faktor atau multi kriteria yang kompleks menjadi suatu hirarki. Hirarki didefinisikan sebagai suatu representasi dari sebuah permasalahan yang kompleks dalam suatu struktur multi level dimana level pertama adalah tujuan, yang diikuti level faktor, kriteria, sub kriteria, dan seterusnya ke bawah hingga level terakhir dari alternatif. Dengan hirarki, suatu masalah yang kompleks dapat diuraikan ke dalam kelompok-kelompoknya yang kemudian diatur menjadi suatu bentuk hirarki sehingga permasalahan akan tampak lebih terstruktur dan sistematis
Analytical Hierarchy Process adalah metode analisa yang digunakan untuk menentukan bentuk partisipasi yang tepat bagi masyarakat Kelurahan Baru Tengah dalam penyediaan air bersih. Analisa ini dilakukan dengan tahapan sebagai berikut:

1. Penentuan Sampel Stakeholder

Tahap ini dilakukan dengan mempertimbangkan siapa saja pihak yang memperoleh manfaat, pihak yang memperoleh kerugian, pihak yang kemungkinan kalah, dan hubungan antar pihak yang bersangkutan. Pada tahap ini, dirinci harapan- harapan apa yang ada dari para setakeholders terhadap kegiatan tersebut, sumber daya yang dapat dimobilisasi masing - masing stakeholders, dan kepentingan masingmasing stakeholders. Berikut merupakan sampel stakeholder yang terlibat dalam analisis AHP:
a. Kelurahan Baru Tengah
b. Dinas Pertanahan dan Penataan Ruang Kota Balikpapan
c. Dinas Pekerjaan Umum Kota Balikpapan
d. Sekretariat Daerah Pemerintah Kota Balikpapan
e. Akademisi

2. Identifikasi Tujuan, Kriteria, dan Alternatif

Tujuan dalam analisis AHP ini adalah Arahan Partisipasi Masyarakat dalam Penyediaan Air Bersih. Kemudian, tingkatan partisipasi menjadi kriteria dalam analisis AHP. partisipasi masyarakat merupakan suatu pola bertingkat yang terdiri dari 8 tingkat yakni Manipulation, Therapy, Informing, Consultation, Placation, Partnership, Delegated Power, dan Citizen Control [6]. Sebagai tingkatan partisipasi yang tidak melibatkan masyarakat, maka tingkatan Manipulation, Therapy, Informing, Consultation, dan Placation tidak dimasukkan sebagai 
kriteria dalam analisis arahan partisipasi.

3. Penyusunan Pohon Hirarki

Hirarki adalah struktur suatu sistem yang menjelaskan fungsi interaksi antar komponen dan juga dampak-dampaknya pada sistem. Penyusunan pohon hirarki dilakukan untuk menggambarkan hubungan elemen kriteria dan alternatif. Pohon hirarki pada analisa ini memiliki tujuan untuk mengetahui partisipasi yang tepat dalam penyediaan air bersih. Kriteria yang digunakan adalah jenis partisipasi meliputi citizen control, delegated power, dan partnership. Ketiga kriteria tersebut menjadi dasar pada alternatif kegiatan partisipasi tenaga, pikiran, dan keahlian (Gambar 1.) pada Keputusan yang teridentifikasi. pohon hirarki dari rumusan arahan partisipasi masyarakat dalam penyediaan air bersih di Kelurahan Baru Tengah.

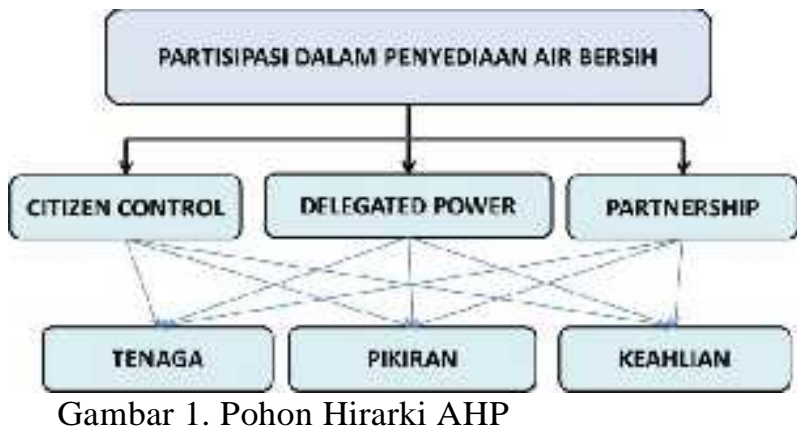

\section{Hasil Penelitian}

Dalam analisis AHP, tingkatan partisipasi masyarakat dimasukkan ke dalam kriteria, dan pemilihan bentuk partisipasi dimasukkan pada tingkatan sub-kriteria. Pemilihan tingkatan partisipasi masyarakat dilakukan oleh para responden yang telah ditentukan sebelumnya.

\subsection{Tingkatan Partisipasi Masyarakat} Matriks gabungan responden untuk tingkatan partisipasi didapatkan dengan perkalian setiap nilai yang diberikan responden, kemudian perkalian tersebut diakar sesuai dengan jumlah responden. Dalam perhitungan ini, responden yang dimasukkan sejumlah lima orang. Sehingga hasil perkalian setiap nilai diakar pangkat lima.

Tabel 1 Matriks Gabungan Nilai Tingkatan Partisipasi

\begin{tabular}{cccc}
\hline & Partnership & $\begin{array}{c}\text { Delegated } \\
\text { Power }\end{array}$ & $\begin{array}{c}\text { Citizen } \\
\text { Control }\end{array}$ \\
\hline $\begin{array}{c}\text { Partnership } \\
\text { Delegated } \\
\text { Power } \\
\text { Citizen }\end{array}$ & 1 & 0,47 & 2,37 \\
Control & 0,42 & 1,06 & 0,93 \\
\hline
\end{tabular}

Tabel gabungan nilai responden pada tingkatan partisipasi masyarakat Kelurahan Baru Tengah menunjukkan bahwa para responden memberikan Partnership nilai lebih rendah dibandingkan Delegated Power. Namun, Partnership memiliki nilai yang lebih tinggi dibandingkan dengan Citizen Control. Terakhir, Citizen Control memiliki nilai lebih tinggi dibandingkan Delegated Power.

Kemudian, perhitungan matriks tingkatan partisipasi masyarakat Kelurahan Baru Tengah dilanjutkan dengan perkalian matriks gabungan nilai responden tingkatan partisipasi masyarakat Kelurahan Baru Tengah dengan matriks itu sendiri. Perkalian matriks gabungan menghasilkan nilai penjumlahan sebesar 11,61 untuk tingkatan partisipasi Partnership, nilai penjumlahan 14,40 untuk tingkatan partisipasi Delegated Power, dan nilai penjumlahan 8,37 untuk tingkatan partisipasi Citizen Control. Hasil-hasil penjumlahan tersebut kemudian dinormalisasi dan menghasilkan nilai eigenvector 0,34 untuk tingkatan partisipasi Partnership, nilai eigenvector 0,42 untuk tingkatan partisipasi Delegated 
Power, dan nilai eigenvector 0,24 untuk tingkatan partisipasi Citizen Control.

Dari tabel hasil perkalian tingkatan partisipasi masyarakat Kelurahan Baru Tengah di atas, dapat dilihat bahwa tingkatan partisipasi Delegated Power adalah tingkatan partisipasi yang paling diprioritaskan dalam penyediaan air bersih berbasis partisipasi masyarakat di Kelurahan Baru Tengah.

\subsection{Bentuk Partisipasi Masyarakat}

Matriks gabungan bentuk partisipasi masyarakat Kelurahan Baru Tengah didapatkan dari hasil perkalian nilai yang diberikan responden, kemudian diakar dengan pangkat yang sesuai dengan jumlah responden. Dalam perhitungan ini, responden yang dimasukkan sejumlah lima orang. Sehingga hasil perkalian setiap nilai diakar pangkat lima. Responden pada bentuk partisipasi masyarakat Kelurahan Baru Tengah sama dengan responden Tingkatan Partisipasi Kelurahan Baru Tengah. Bentuk partisipasi meliputi tenaga, pikiran, dan keahlian [7].

Tabel 2. Matriks Gabungan Nilai Bentuk Partisipasi Untuk Tingkatan Partisipasi "Partnership",

\begin{tabular}{lccc}
\hline & Tenaga & Pikiran & Keahlian \\
\hline Tenaga & 1 & 2,63 & 1,38 \\
Pikiran & 0,38 & 1 & 0,30 \\
Keahlian & 0,72 & 2,10 & 1
\end{tabular}

Tabel gabungan nilai responden pada bentuk partisipasi masyarakat Kelurahan Baru Tengah dalam tingkatan partisipasi Partnership menunjukkan bahwa para responden memberikan bentuk partisipasi Tenaga nilai lebih tinggi dibandingkan Pikiran. Tenaga juga memiliki nilai yang lebih tinggi dibandingkan dengan Keahlian. Namun, Keahlian memiliki nilai lebih tinggi dibandingkan Pikiran.
Perhitungan prioritas bentuk pasrtisipasi masyarakat Kelurahan Baru Tengah dilakukan dengan membuat perkalian matriks gabungan bentuk partisipasi masyarakat Kelurahan Baru Tengah dengan Matriks itu sendiri. Sehingga akan memunculkan nilai penjumlahan dan eigenvector seperti pada perkalian matriks tingkatan partisipasi

Perkalian matriks gabungan sub-kriteria Partnership menghasilkan nilai penjumlahan sebesar 14,70 untuk bentuk partisipasi Tenaga, nilai penjumlahan 4,73 untuk bentuk partisipasi Pikiran, dan nilai penjumlahan 10,95 untuk bentuk partisipasi Keahlian. Hasil-hasil penjumlahan tersebut kemudian dinormalisasi dan menghasilkan nilai 0,48 untuk bentuk partisipasi Tenaga, nilai 0,16 untuk bentuk partisipasi Pikiran, dan nilai 0,36 untuk bentuk partisipasi Keahlian. Pada hasil perhitungan ini, bentuk partisipasi Tenaga memiliki nilai Eigenvector paling besar dalam sub-kriteria Partnership. Artinya, bentuk partisipasi Tenaga adalah bentuk partisipasi yang diprioritaskan oleh responden dalam tingkatan partisipasi Partnership.

Tabel 3 Matriks Gabungan Nilai Bentuk Partisipasi Untuk Tingkatan Partisipasi "Delegated Power"

\begin{tabular}{lccc}
\hline & Tenaga & Pikiran & Keahlian \\
\hline Tenaga & 1 & 0,33 & 0,89 \\
Pikiran & 3,00 & 1 & 1,72 \\
Keahlian & 1,12 & 0,58 & 1 \\
\hline
\end{tabular}

Tabel gabungan nilai responden pada bentuk partisipasi masyarakat Kelurahan Baru Tengah dalam tingkatan partisipasi Delegated Power menunjukkan bahwa para responden memberikan bentuk 
partisipasi Tenaga nilai lebih rendah dibandingkan Pikiran. Tenaga juga memiliki nilai yang lebih rendah dibandingkan dengan Keahlian. Keahlian memiliki nilai lebih rendah dibandingkan Pikiran.

Perkalian matriks gabungan subkriteria Delegated Power menghasilkan nilai penjumlahan sebesar 6,52 untuk bentuk partisipasi Tenaga, nilai penjumlahan 17,03 untuk bentuk partisipasi Pikiran, dan nilai penjumlahan 8,50 untuk bentuk partisipasi Keahlian. Hasil-hasil penjumlahan tersebut kemudian dinormalisasi dan menghasilkan nilai 0,20 untuk bentuk partisipasi Tenaga, nilai 0,53 untuk bentuk partisipasi Pikiran, dan nilai 0,27 untuk bentuk partisipasi Keahlian. Pada hasil perhitungan ini, bentuk partisipasi Pikiran memiliki nilai Eigenvector paling besar dalam sub-kriteria Partnership. Artinya, bentuk partisipasi Pikiran adalah bentuk partisipasi yang diprioritaskan oleh responden dalam tingkatan partisipasi Delegated Power.

Tabel 4. Matriks Gabungan Nilai Bentuk Partisipasi Untuk Tingkatan Partisipasi "Citizen Control"

\begin{tabular}{lccc} 
& Tenaga & Pikiran & Keahlian \\
\hline Tenaga & 1 & 0,38 & 0,47 \\
Pikiran & 2,63 & 1 & 0,90 \\
Keahlian & 2,10 & 1,10 & 1 \\
\hline
\end{tabular}

Tabel gabungan nilai responden pada bentuk partisipasi masyarakat Kelurahan Baru Tengah dalam tingkatan partisipasi Citizen Control menunjukkan bahwa para responden memberikan bentuk partisipasi Tenaga nilai lebih rendah dibandingkan Pikiran. Tenaga juga memiliki nilai yang lebih rendah dibandingkan dengan Keahlian. Namun, Keahlian memiliki nilai lebih tinggi dibandingkan Pikiran.

Perkalian matriks gabungan sub-kriteria Citizen Control menghasilkan nilai penjumlahan sebesar 4,68 untuk bentuk partisipasi Tenaga, nilai penjumlahan 13,28 untuk bentuk partisipasi Pikiran, dan nilai penjumlahan 23,11 untuk bentuk partisipasi Keahlian. Hasil-hasil penjumlahan tersebut kemudian dinormalisasi dan menghasilkan nilai 0,11 untuk bentuk partisipasi Tenaga, nilai 0,32 untuk bentuk partisipasi Pikiran, dan nilai 0,57 untuk bentuk partisipasi Keahlian. Pada hasil perhitungan ini, bentuk partisipasi Keahlian memiliki nilai Eigenvector paling besar dalam subkriteria Citizen Control. Artinya, bentuk partisipasi Keahlian adalah bentuk partisipasi yang diprioritaskan oleh responden dalam tingkatan partisipasi Citizen Control.

Masing-masing tingkatan partisipasi mempunyai bentuk partisipasi yang diprioritaskan. Berdasarkan perhitungan tersebut, dapat dilihat bahwa bentuk partisipasi Tenaga adalah bentuk partisipasi yang paling diprioritaskan dalam tingkatan partisipasi "Partnership". Kemudian, bentuk partisipasi Pikiran adalah bentuk partisipasi yang paling diprioritaskan dalam tingkatan partisipasi "Delegated Power", dan bentuk partisipasi Keahlian adalah bentuk partisipasi yang paling diprioritaskan dalam tingkatan partisipasi "Citizen Control" pada penyediaan air bersih berbasis partisipasi masyarakat di Kelurahan Baru Tengah.

\section{Kesimpulan}

Partisipasi yang dapat dilakukan oleh masyarakat Kelurahan Baru Tengah dalam penyediaan air bersih adalah pada tingkatan Delegated Power. Delegated Power ialah partisipasi yang melibatkan masyarakat untuk berperan sebagai pihak yang mempunyai wewenang untuk 
mengambil keputusan terkait penyediaan air bersih. Bentuk partisipasi yang dapat digunakan dalam penyediaan air bersih berbasis partisipasi ialah melalui sumbangsih berupa pikiran.

\section{Saran}

Berdasarkan penelitian ini, saran yang dapat diberikan kepada pemerintah ialah dalam penyediaan air bersih, masyarakat dapat ikut diturutsertakan dalam kinerjanya. Masyarakat dapat diberi kesempatan untuk mengambil keputusan, memberikan ide, serta mengevaluasi kinerja pemerintah dan juga kinerja swadaya masyarakat.

Saran yang dapat diberikan untuk akademisi antara lain dalam melakukan penelitian dapat juga disertai dengan identifikasi karakteristik masyarakat pada wilayah penelitian meliputi kondisi sosial budaya dan ekonomi. Selain itu juga dalam melakukan penelitian, bentuk penyediaan air bersih yang diidentifikasi juga dapat diarahkan pada satu bentuk penyediaan tertentu untuk tujuan yang lebih spesifik.

Saran yang dapat diberikan untuk masyarakat antara lain:

a. Masyarakat dapat ikut serta mendukung upaya pemerintah dalam pengembangan infrastruktur, khususnya penyediaan air bersih, karena air bersih yang dihasilkan akan memberikan manfaat pada masyarakat juga.

b. Masyarakat dapat turut serta lebih aktif dalam memberikan ide atau pikiran terkait

\section{Daftar Pustaka}

[1] Afandi, M. N. (2012, Oktober 22). Pembangunan Infrastruktur Sebagai Pendukung. Dipetik April 17, 2016, dari STIA LAN Bandung: http://stialanbandung.ac.id

[2] Santono, H. (2010). Air Bersih dan Sanitasi sebagai Kebijakan Sosial. Jakarta: Komunitas Indonesia untuk Demokrasi.

[3] BPS Kota Balikpapan. (2015). Kecamatan Balikpapan Barat dalam Angka 2015. Balikpapan: Badan Pusat Statistik Kota Balikpapan.

[4] Dokumen Hukum, Peraturan dan Perundangan Badan Perencanaan dan Pembangunan Daerah Balikpapan (2016). Rencana Detail Tata Ruang Kota Balikpapan

[5] Veronika, A., Trigunarsyah, B., Latief, Y., \& Abidin, I. (2005). Rekomendasi Tindakan Koreksi Terhadap Penyimpangan Biaya Pembelian Material Konstruksi. Jurnal Sipil Vol. 12 No. 3 , 159-166.

[6] Arnstein, S. (1969). A Ladder of Citizen Participation. London: Routledge Press

[7] Wedam, E., Quansah, J. D., \& Debrah, I. A. (2015). Community Participation in Educational Infrastructure Development and Management in Ghana. Scientific \& Academic Publishing , 129-141 